\title{
Longevity of dams from landslides with sub-channel rupture surfaces, Peace River region, Canada
}

\author{
Brendan Miller ${ }^{1 *} \mathbb{D}$, Anja Dufresne ${ }^{2}$, Marten Geertsema ${ }^{1}$, Nigel Atkinson ${ }^{3}$, Heidi Evensen $^{4}$ and David Cruden ${ }^{5}$
}

\begin{abstract}
Background: We examined seven landslide dams and their changes over time in the Peace River region of Canada. These landslides had subchannel rupture surfaces in glacial and glaciolacustrine sediments. We assessed the stability of the dams using 6 separate, morphometric-based stability indices (with a total of 10 stability thresholds).

Results: The landslides caused the streambeds to be elevated from 4 to $30 \mathrm{~m}$ forming the dams. The landslide lakes diminished in size over one to several years through stream incision into the dams and sediment infilling. The longest-lived dam persisted for up to 20 years. For two dams, incision into the dams lowered the lake levels by about half of the total depth, while the remainder of the water in the basins was displaced by sediment infilling. After the lakes drain, the sediment accumulations behind the dams can persist for decades. The stability analyses overpredicted unstable conditions which is inconsistent with the observed longterm persistence of the dams.

Conclusions: The landslide dams in our study were relatively stable. Their lakes persisted for up to 2 decades and diminished over time through a combination of slow incision and basin infilling. The stability indices we assessed overpredicted unstable conditions and thus would require modification for these particular types of dams in this regional setting.
\end{abstract}

Keywords: Landslide, Dam, Stability, Peace River, Quaternary, Sediment

\section{Background}

Large landslides in Quaternary sediments are commonplace in the Peace River regions of Alberta and British Columbia (Geertsema et al. 2006; Miller and Cruden 2008), and many of the landslides create dams which disrupt streamflow, damage timber, and threaten infrastructure both downstream and upstream.

On smaller streams, with narrow valleys, large landslides tend to fully obstruct the valleys, creating lakes that can persist for decades (Lu et al. 1998; Miller and Cruden 2001, 2002, 2008, 2014; Geertsema and Clague 2006, 2008). In contrast, regional dams on the larger systems are generally short-lived (for example, the Attachie dam on the Peace River (Evans et al. 1996,

\footnotetext{
* Correspondence: brendan.miller@gov.bc.ca

${ }^{1}$ British Columbia Ministry of Forests, Lands, Natural Resource Operations and Rural Development, 499 George Street, Prince George, BC V2L 1R5, Canada Full list of author information is available at the end of the article
}

Fletcher et al. 2002) and the Halfway River dam (Bobrowsky and Smith 1992) lasted for a few hours).

Here we examine seven landslide dams on small tributaries of the Peace River, including: the Eureka River dam (Miller 2000; Miller and Cruden 2001, 2002, 2008, 2014), the Fox Creek dam (Kim et al. 2010), the Hines Creek dam (Lu et al. 1998; Miller and Cruden 2001, 2008), the Montagneuse River dam (Cruden et al. 1997; Miller and Cruden 2008), the Pouce Coupe River dam (British Columbia 2014), the Saddle River dam (Cruden et al. 1993; Alberta 1997; Miller and Cruden 2001, 2008, 2014), and the Spirit River dam (Miller 2000; Miller and Cruden 2001, 2008, 2014) (Fig. 1).

We classified landslides according to Cruden and Varnes (1996) and landslide dams according to Costa and Schuster (1988), where six dam types are described: I) Partial, II) Complete, III) Divergent, IV) Convergent, V) Multi-lobed, and VI) Uplifted (from Cruden and Van Dine 2013). The landslide dams we describe are all Type VI. Type VI dams 


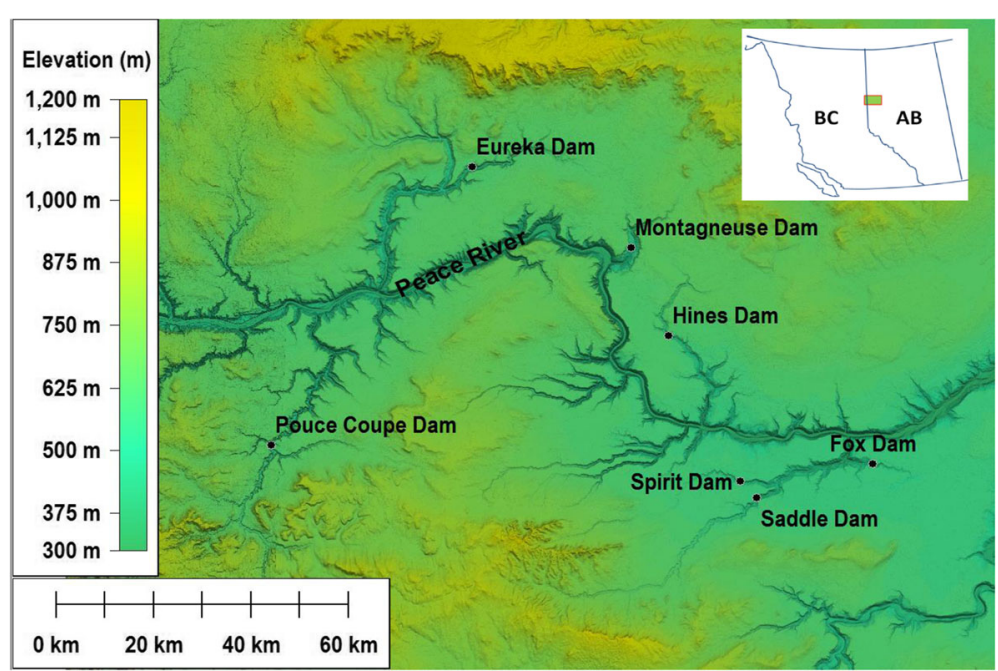

Fig. 1 Locations of the landslide dams. The regional topography was generated using digital topographic data from Natural Resources Canada (licenced under the Open Government Licence - Canada). The Peace River region is a broad, gently sloping plain which is deeply dissected by Holocene streams. The inset map shows the general study location (green box) in relation to the boundaries of the provinces of Alberta and British Columbia, Canada

form when a landslide's rupture surface extends under a stream channel, and emerges on the opposite valley side from the landslide, causing the channel to be displaced upwards and the stream flow to be impeded (Costa and Schuster 1988).

We have assessed dam stability using 6 separate indices (with a total of 10 stability thresholds) based on watershed and dam morphometric attributes (from: Canuti et al. 1998; Casagli and Ermini 1999; Ermini and Casagli 2003; Korup 2004; Tacconi Stefanelli et al. $2015,2016,2017)$. This assessment tests the applicability of these indices and thresholds on these dams, in our regional setting.

The aims of this paper are to describe the landslide dams, the evolution of the dams and their lakes over time, and to test various dam stability indices.

\section{Setting and stratigraphy \\ General description}

Our Peace River study area is situated on a flat to rolling dissected plain, located east of the Rocky Mountains, in northeastern British Columbia and northwestern Alberta (Fig. 1). The Peace River and its tributaries dissect glacial and non-glacial sediments as well as shale and sandstone bedrock (Holland 1976; Morgan et al. 2012). The area has a continental climate, characterized by warm, wet summers and cold, dry winters (Foord 2016).

Previous work in the region has determined the Quaternary stratigraphy of the Peace River and its tributaries (Bayrock 1969; Fenton 1984; Liverman et al. 1989; Catto et al. 1996; Hartman and Clague 2008), with recent studies generalizing the sedimentary succession into five major lithotype assemblages (LTAs)
(Atkinson and Paulen 2010, Morgan et al. 2012, and references therein, Fig. 2).

The five major LTAs, from highest (youngest) to lowest (oldest), can be summarized as follows:

- LTA5 retreat phase glaciolacustrine sediment;

- LTA4 glacial sediment (including till);

- LTA3 advance phase glaciolacustrine sediment;

- LTA2 massive sands (with bone dates of $25.1 \mathrm{ka} \mathrm{BP);}$ and

- LTA1 preglacial sands and gravels (with wood dates between 43.5 and $27.4 \mathrm{ka} \mathrm{BP}$ ).

This stratigraphy records the up-valley advance of the Laurentide Ice Sheet and subsequent down-valley ice front retreat, and the preceding non-glacial intervals (Hartman and Clague 2008). These events filled the pre-glacial topography with up to $200 \mathrm{~m}$ of Quaternary sediment.

\section{Stratigraphy, erosion, and landslides}

The distribution of deep-seated landslides correlates with the location of buried pre-glacial valleys of the ancestral Peace River and its tributaries. The ice- advancephase glaciolacustrine (LTA3, Fig. 3) sediment has been recognized as a prominent décollement plane for several deep-seated failures (Cruden et al. 1993, 1997; Miller 2000; Miller and Cruden 2001, 2002; Geertsema et al. 2006; Kim et al. 2010; Morgan et al. 2012).

Figure 2 plots variable valley slopes (normal to valley axis) against the regional stratigraphy for segments of Clear and Eureka rivers, and the Saddle and Spirit rivers. The top of the plots represent the valley slope angles associated with stream incision into the uppermost 


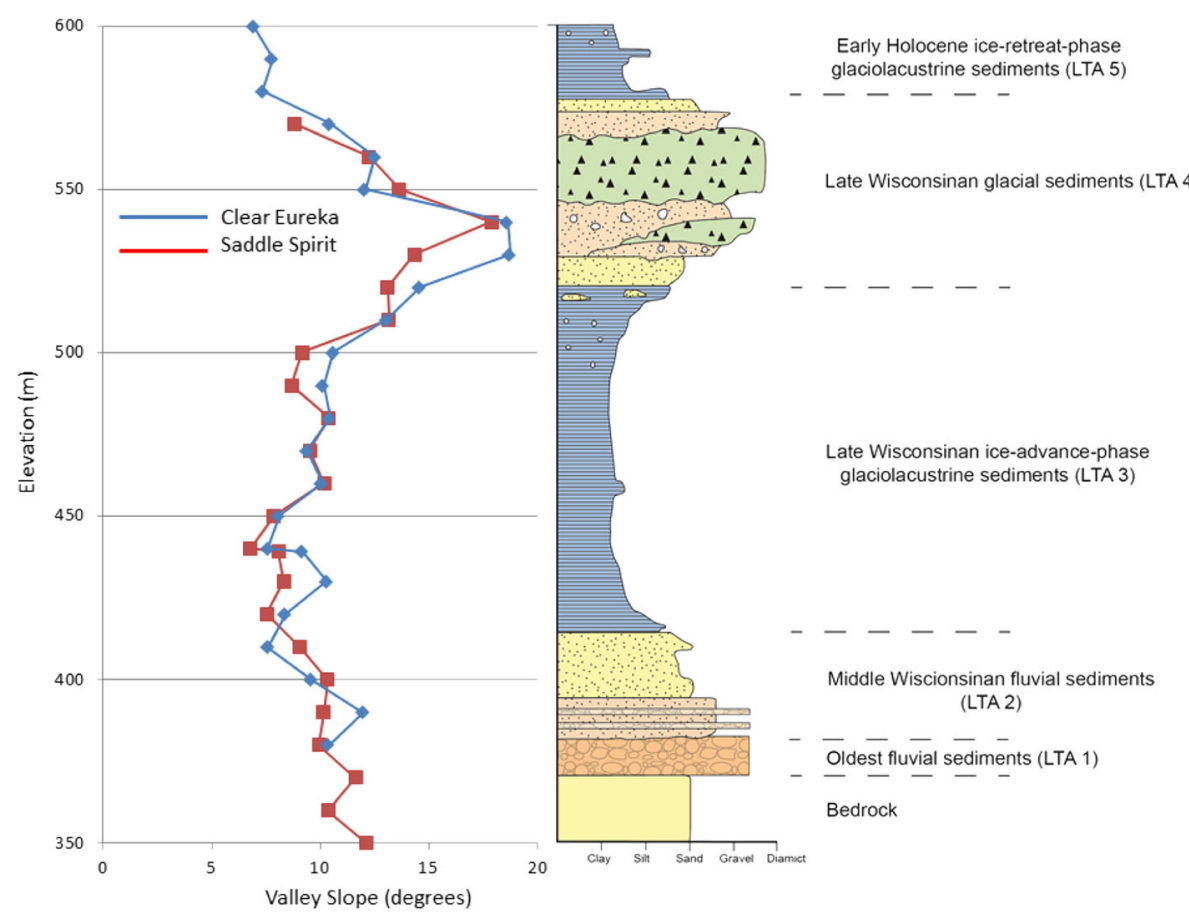

Fig. 2 Generalized stratigraphy found within buried preglacial valleys in the Peace River lowlands (right; modified after Morgan et al. 2012), and (left) average valley slopes of the lower Clear River (to the Eureka River) and the Eureka River (blue), and the lower Saddle River (to the Spirit River) and the Spirit River (red). Five of the landslides described appear be associated with ice-advance -phase glaciolacustrine sediment (LTA3), and two with the lower portion of the glacial sediments (LTA4). The valley slopes appear to reflect the stratigraphy. The slopes are lowest where the rivers are incising through LTA3 or LTA5, and steepen where the river incises into LTA4. Note that thickness of LTA4 has been exaggerated in this diagram, as the diamict is not topography constrained and will impact the valley slope response to incision over a longer distance than the unit thickness would otherwise suggest

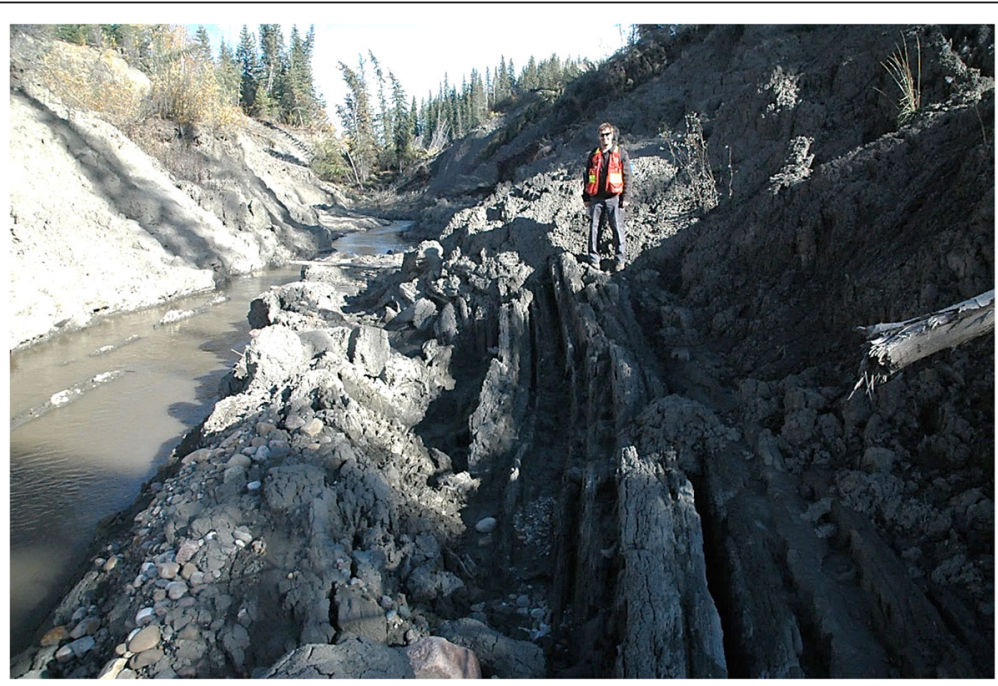

Fig. 3 Upthrust advance phase glacial lacustrine sediment (LTA3) at the toe of the Eureka River landslide. The reorientation of the lacustrine rhythmites to near vertical, was likely caused by the landslide. Note the scattering of boulders and cobbles at discrete locations. This material likely originated in the pre-landslide channel and was introduced into the post-landslide channel by bank erosion. Also note the small landslide into the channel in the distance. (Source: BGN Miller, September 28, 2007) 
sedimentary unit, at the upper reaches of the streams; whereas, the bottom of the plots represent slope angles from stream incision through the entire sedimentary sequences. Postglacial stream incision through the stratigraphic sequence in Fig. 2 may have progressed as follows:

- Initial incision through the uppermost glaciolacustrine sediments (LTA5), resulting in slope angles from 5 to 10 degrees.

- Subsequent incision into the more stable glacial sediment (LTA4), resulting in slope angles of up to 18-degrees.

- Further incision into the advance-phase glaciolacustrine sediment (LTA3), where slopes decrease to as low as 6 degrees.

- Final incision into the lower fluvial units (LTA1 and 2) and into bedrock, where slopes increase to near 10 degrees.

\section{Methods}

We described the landslides and landslide dams using information predominently from previous studies and government reports. We used aerial and satellite imagery, coupled with field observations, to measure and characterize the changes in the landslide dams and lakes over time. We analysed lidar data in a Geographic Information System (GIS) to determine the amount of stream incision into the dams and the depths of basin sediment infilling. For the dam stability analyses, we used indices drawn from literature and compared the results to the observed behaviours. We derived morphometric attribute values for the stability analyses from Natural Resource Canada digital elevation data and LiDAR data in a GIS.

\section{Results}

\section{Peace River regional landslide dams}

The following provides a description of seven landslide dams and their development over time (Tables 1 and 2, Fig. 4).

\section{Eureka River landslide dam}

The Eureka River landslide (Fig. 5) was an enlarged translational earth slide with an estimated volume of $50 \mathrm{Mm}^{3}$ (Miller 2000; Miller and Cruden 2002). The landslide occurred sometime between 28 October 1989 and 28 March 1990, based on bracketing Landsat 5 Thematic Mapper images. The landslide's rupture surface, in advance phase glaciolacustrine sediment (LTA3), extended beneath the streambed causing it to be elevated by approximately $20 \mathrm{~m}$, creating a Type VI landslide dam.

The old channel was abandoned and a new channel formed around the toe of the landslide. Initially, coarse alluvium was generally absent in the new channel, allowing for rapid stream incision to occur - up to $20 \mathrm{~m}$ in a decade near the centre of the landslide. This rapid incision promoted extensive instability from both banks, and reintroduced coarse alluvium (cobbles and boulders) from the pre-slide channel into the new channel (Fig. 3). This coarse material however, had a short residence time in the channel and was quickly mobilized downstream, leaving the channel base unprotected.

Following an initial lake length of about $7 \mathrm{~km}$ (1990), the lake began to get progressively smaller as a result of slow dam incision (Table 2). Incision was slowed when the post landslide channel encountered the uplifted prelandslide channel, near the upstream edge of the landslide dam. After about 20 years the lake ceased to exist from a combination of sedimentary infilling and dam incision. A lidar-generated longitudinal profile of Eureka River shows approximately $8 \mathrm{~m}$ of sediment accumulation occurred within the landslide lake basin (Fig. 6). As the landslide dam height was estimated to be $20 \mathrm{~m}$, incision into the dam lowered the lake by approximately $12 \mathrm{~m}$, whereas sediment infilling of the basin amounted to $8 \mathrm{~m}$.

\section{Fox Creek landslide dam}

The May 5, 2007 Fox Creek landslide was a rapid translational block slide involving about $47 \mathrm{Mm}^{3}$ of Quaternary sediments (Kim et al. 2010; Fig. 7). The basal rupture surface of the landslide, in advance-phase glaciolacustrine

Table 1 Landslide and landslide dam attributes

\begin{tabular}{|c|c|c|c|c|c|}
\hline Landslide & year & Landslide Volume $\left(\mathrm{Mm}^{3}\right)$ & Dam Height $(m)$ & Dam Width (m) & Lake Duration (years) \\
\hline Eureka River & 1989-90 & 50 & 20 & 1000 & $<20$ \\
\hline Fox Creek & 2007 & 47 & 19 & 1700 & $>10$ \\
\hline Hines Creek & 1990 & $x$ & 25 & $120-150$ & $<7$ \\
\hline Hines Creek & Pre-1952 & 48 & $x$ & 1000 & $x$ \\
\hline Montagneuse River & 1939 & 78 & 30 & $x$ & $x$ \\
\hline Pouce Coupe River & 2013 & $1-3$ & 4 & 170 & $<1$ \\
\hline Saddle River & 1990 & 39 & 24 & 800 & $<17$ \\
\hline Spirit River & 1995 & 20 & 9 & $x$ & $>18$ \\
\hline
\end{tabular}

Notes: $\mathrm{X}=$ No Data 
Table 2 Changes in the landslide lakes lengths over time with data sources and approximate ground resolution indicated

\begin{tabular}{|c|c|c|c|}
\hline Date & Lake Length (km) & Source & Data Resolution (m) \\
\hline \multicolumn{4}{|l|}{ Eureka River } \\
\hline Sep 29, 1990 & 7 & Landsat 5 Thematic Mapper & 30 \\
\hline Oct 6, 1992 & 6 & Alberta Air Photo AS4892, 148 & ${ }^{a} 1$ \\
\hline Sep 1, 1997 & 2.9 & Alberta Air Photo AS4892, 148 & $\mathrm{a}_{1}$ \\
\hline Aug 1999 & 1.7 & Field Survey & NA \\
\hline Aug 25, 2006 & 0.7 & Alberta Air Photo AS5379B, 15 & $\mathrm{a}_{1}$ \\
\hline May 28, 2009 & 0.1 & RapidEye & $3-5$ \\
\hline Jun 7, 2009 & 0 & RapidEye & $3-5$ \\
\hline \multicolumn{4}{|l|}{ Fox Creek } \\
\hline 28 Aug, 2007 & 1.6 & Landsat 7 Enhanced Thematic Mapper & 30 \\
\hline Jun 17, 2010 & 1.1 & RapidEye & $3-5$ \\
\hline May 15, 2011 & 1 & RapidEye & $3-5$ \\
\hline Sep 172012 & 1 & Digital Globe & 0.5 \\
\hline Sep 19, 2013 & 0.8 & Digital Globe & 0.5 \\
\hline Jul 4, 2014 & 0.6 & RapidEye & $3-5$ \\
\hline Jun 3, 2015 & 0.6 & RapidEye & $3-5$ \\
\hline May 23, 2016 & 0.1 & RapidEye & $3-5$ \\
\hline Jun 10, 2017 & 0.1 & RapidEye & $3-5$ \\
\hline \multicolumn{4}{|l|}{ Hines Creek } \\
\hline Jun 25, 1991 & 1.7 & Landsat 5 Thematic Mapper & 30 \\
\hline Jun 14,1992 & 1.5 & Landsat 5 Thematic Mapper & 30 \\
\hline Aug 17, 1992 & 1.4 & Alberta Air Photo AS4314-251 & $\mathrm{a}_{1}$ \\
\hline Jun 26, 1993 & 1.5 & Landsat 5 Thematic Mapper & 30 \\
\hline Jun 20, 1994 & 1.2 & Landsat 5 Thematic Mapper & 30 \\
\hline Jun 16,1995 & 1.0 & Landsat 5 Thematic Mapper & 30 \\
\hline Jun 25, 1996 & 0.9 & Landsat 5 Thematic Mapper & 30 \\
\hline Oct 8, 1996 & 0.7 & Landsat 5 Thematic Mapper & 30 \\
\hline Apr 18, 1997 & 0 & Landsat 5 Thematic Mapper & 30 \\
\hline \multicolumn{4}{|c|}{ Pouce Coupe River } \\
\hline Aug 23, 2013 & 2.0 & RapidEye & $3-5$ \\
\hline Sep 3, 2013 & 2.0 & Landsat 8 Operational Land Imager & 30 \\
\hline Sep 12, 2013 & 2.0 & Landsat 8 Operational Land Imager & 30 \\
\hline Oct 13, 2013 & 2.0 & Landsat 7 Enhanced Thematic Mapper & 30 \\
\hline Apr 8, 2014 & 0 & Landsat 8 Operational Land Imager & 30 \\
\hline \multicolumn{4}{|l|}{ Saddle River } \\
\hline Mar 30, 1991 & 5.7 & Landsat 5 Thematic Mapper & 30 \\
\hline Sep 19, 1995 & 2.8 & Alberta air photo AS4680-33 & $\mathrm{a}_{1}$ \\
\hline Sep 17, 2001 & 1.0 & Alberta air photoAS5194B-40 & ${ }^{\mathrm{a}} 1$ \\
\hline May 2, 2005 & 0.5 & Landsat 7 Enhanced Thematic Mapper & 30 \\
\hline Aug 13, 2006 & 0 & Alberta air photo TRSG0602-1536 & ${ }^{a} 1$ \\
\hline \multicolumn{4}{|l|}{ Spirit River } \\
\hline Sep 19, 1995 & 2.1 & Alberta Air Photo AS4680-32 & $\mathrm{a}_{1}$ \\
\hline Jul 1999 & 0.7 & Field Survey & NA \\
\hline Sep 19, 2013 & 0.3 & Digital Globe & 0.5 \\
\hline
\end{tabular}

Notes: ${ }^{\mathrm{a}} 1$ - objects on the ground of less than $1 \mathrm{~m}$ can be recognized using film-based air photos 


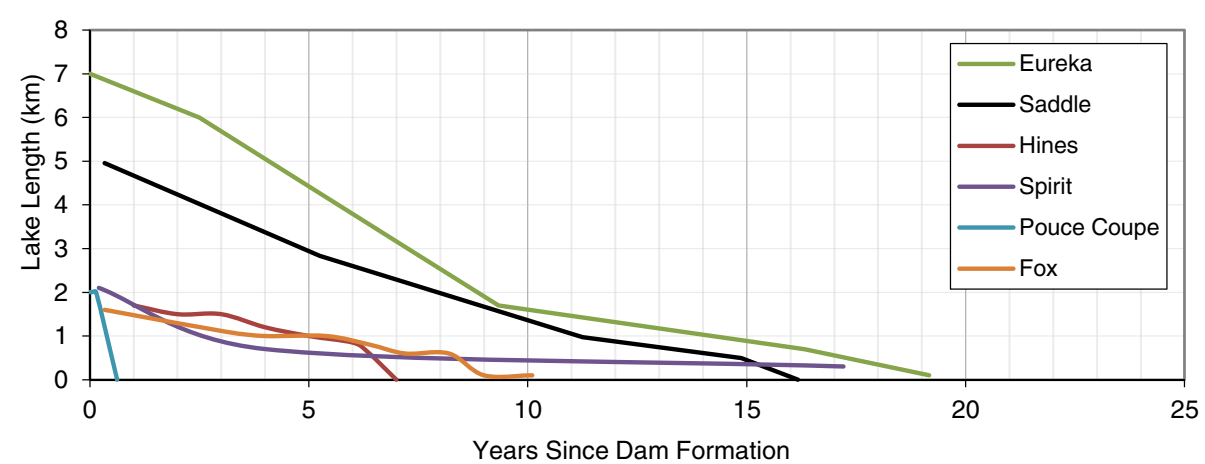

Fig. 4 Changes in the lengths of 6 landslide lakes over time, since the formation of the landslide dams. The data used to derive these curves forms Table 2. The lake lengths go to unity through a combination of incision into the landslide dams and sediment infilling of the basins

sediment (LTA3), extended beneath Fox Creek, causing the stream bed to be elevated and creating a Type VI landslide dam (Kim et al. 2010). The abandoned, pre-landslide stream bed was evident at the toe of the slope.

The landslide dam was a maximum of $19 \mathrm{~m}$ in height, with a width of $1.7 \mathrm{~km}$ (Kim et al. 2010). The largest of the resultant lakes extended upstream beyond the east flank of the landslide for approximately $1.5 \mathrm{~km}$. Two smaller lakes formed atop the landslide debris. An analysis of $2 \mathrm{~m}$ Alberta lidar data, collected on October 22, 2013, shows the stream's longitudinal profile having not substantially recovered from the landslide event (Fig. 8).

\section{Hines Creek landslide dam}

The Hines Creek landslide occurred between June 9th and June 25th, 1990 (based on Landsat 5 Thematic Mapper bracketing dates) and was a reactivated, retrogressive earth slide, with a rupture surface in glacial sediment (LTA4). The landslide formed a Type VI landslide dam, with an estimated height of $25 \mathrm{~m}$ dam, and a lake length of 1.5 to $1.7 \mathrm{~km}$ (Lu et al. 1998).

The 1990 Hines Creek landslide occurred on the opposite valley wall of a much larger landslide. This larger landslide predates the earliest provincial aerial photographic coverage of the site, in 1952. Lu et al. (1998) speculate that the pre-1952 landslide was a major contributing factor to the occurrence of the 1990 landslide, as it directed the stream into the opposite valley wall, causing undercutting of the slope. They estimated the volume of the pre-1952 landslide to be $48 \mathrm{Mm}^{3}$. An extensive sedimentary deposit formed upriver of the pre-1952 landslide, which persisted until at least 1988 (Alberta air photo AS3729-88).

\section{Montagneuse River landslide dam}

The April 1939 Montagneuse River landslide was a reactivated, retrogressive earth slide that moved in translation

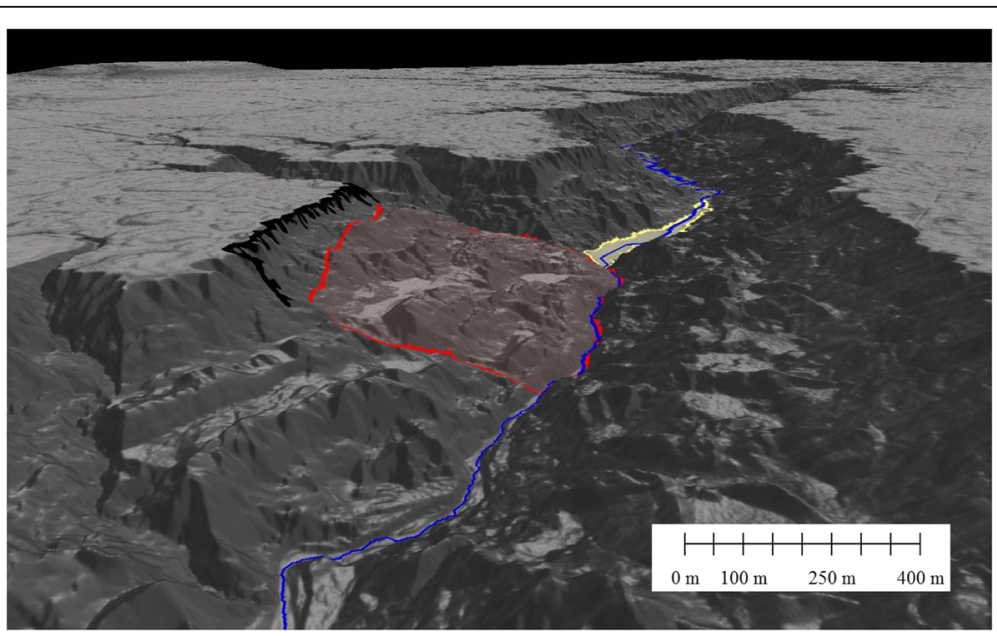

Fig. 5 Oblique perspective of the Eureka River landslide and dam, using a Digital Elevation Model derived from lidar data (dated September 26, 2013; source: Government of Alberta, reproduced with permission), at 2-times vertical exaggeration. The lidar data was collected approximately 4 years after the landslide lake had drained. The red polygon delineates the landslide colluvium, and the black hatched line delineates the landslide's main scarp. The yellow polygon delineates an area of thick lacustrine sediment accumulation (up to $8 \mathrm{~m}$ ), deposited within the landslide lake basin. The blue line traces the post-landslide dam Eureka River. The scale bar is accurate at the downstream (proximal) edge of the landslide colluvium 


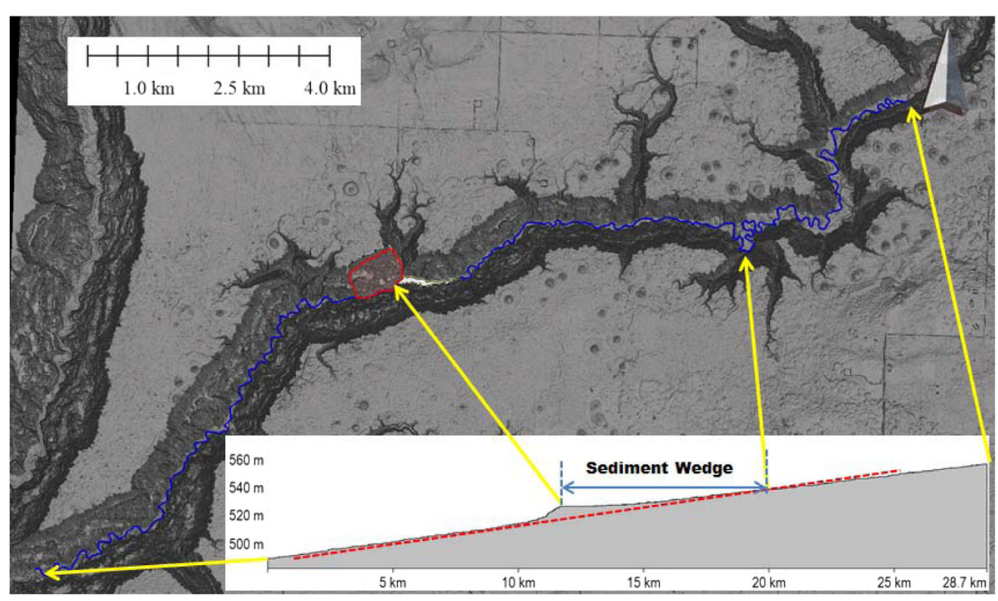

Fig. 6 Plan view and channel longitudinal profile of the lower Eureka River, generated from lidar data (dated September 26, 2013; source: Government of Alberta, reproduced with permission). The red line (cross-section) roughly follows the longitudinal profile of the lower Eureka River (below the landslide). The grey area situated above red line indicates areas of lacustrine and deltaic sedimentation upstream of the landslide dam

(Cruden et al. 1997). The landslide's rupture surface, in advance phase glaciolacustrine sediment (LTA3), extended under the channel creating a Type VI landslide dam (Cruden et al. 1997, Fig. 9). The estimated height of the dam was $30 \mathrm{~m}$. Anecdotal information indicates that the dam stopped the flow in the river for about 2 weeks, causing a $4 \mathrm{~km}$ lake to form.

By June 15, 1945, the lake had drained (Canada air photo A8108, 23-25). Cruden et al. (1997) mapped lacustrine deposits extending about $1.5 \mathrm{~km}$ upstream of the landslide dam using 1952 aerial photographs. They noted that by 1988, the sedimentary deposit had been eroded away.

\section{Pouce Coupe River landslide dam}

The Pouce Coupe River was dammed by a landslide on August 21, 2013. The landslide originated from the east bank of the river, approximately $210 \mathrm{~m}$ downstream from the Landry Bridge (Fig. 10). The landslide caused the river bed to be elevated by approximately $3.8 \mathrm{~m}$, forming a Type VI landslide dam (Fig. 11). An Environment Canada water monitoring station, located immediately downstream from the Landry Bridge, recorded the backing up of the river over a 2.5 day period (British Columbia 2014). Following the landslide, a new channel formed across a

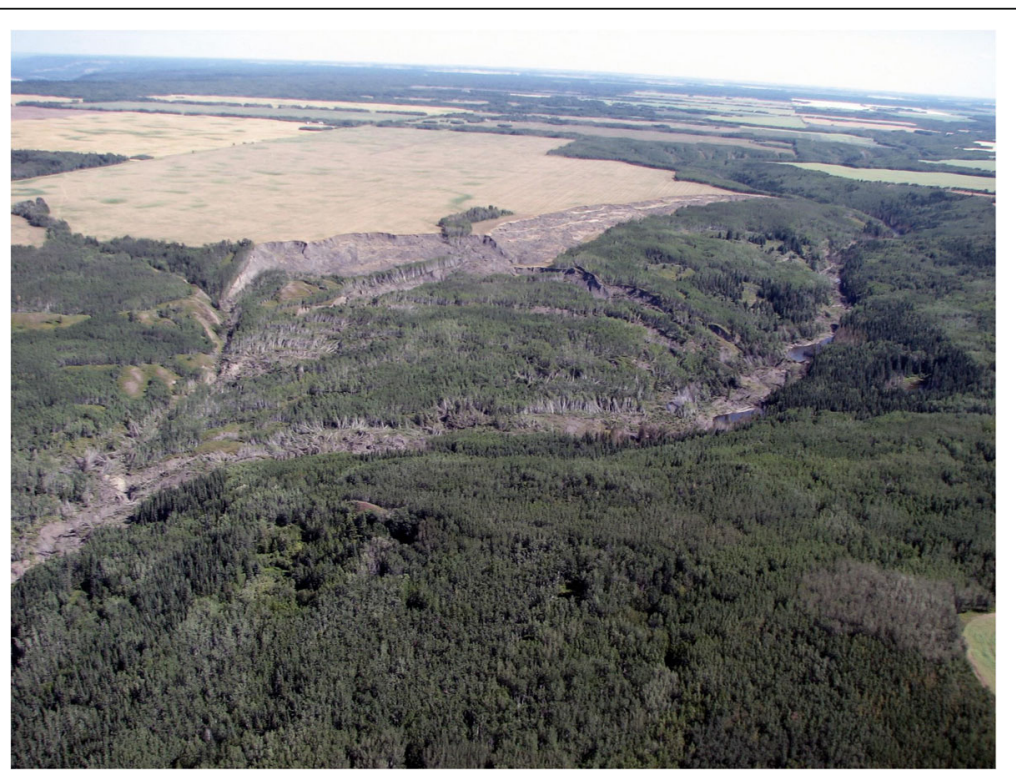

Fig. 7 Oblique air photo of the 2007 Fox Creek landslide, dam and lake, looking upstream. Note that much of the timber atop the landslide remained upright. (Source: Alberta Geological Survey, 2009; reproduced with permission) 


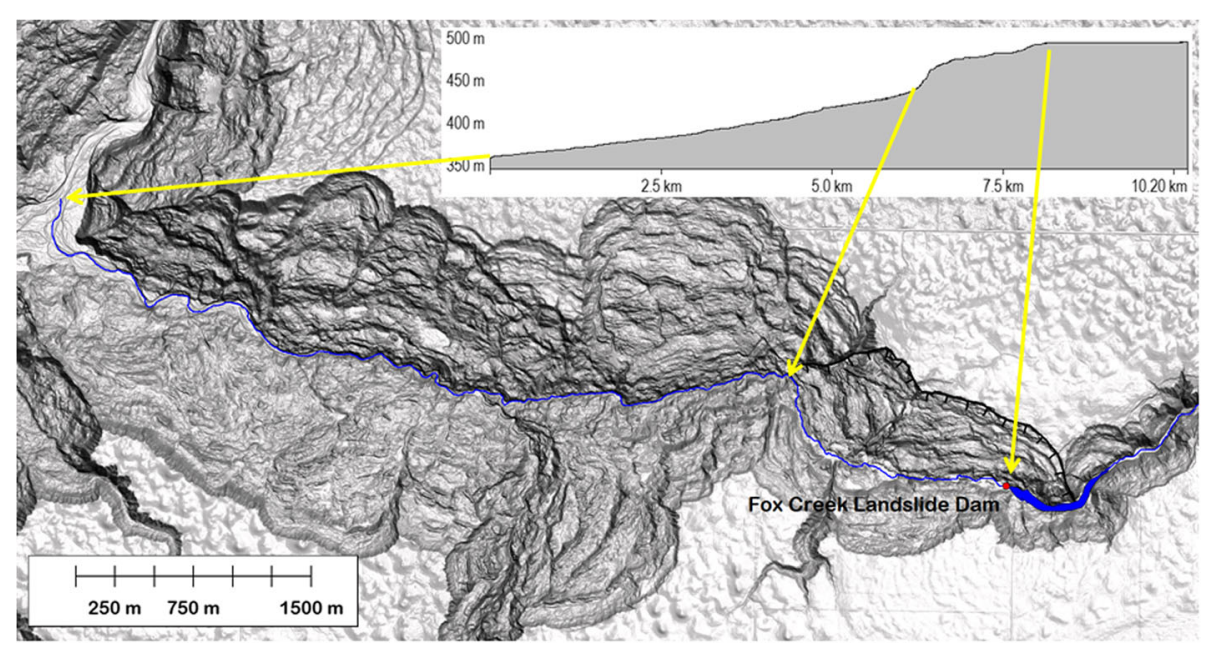

Fig. 8 Plan view and channel longitudinal profile of Fox Creek, generated from 2 m lidar (dated October, 22, 2013; source: Government of Alberta, reproduced with permission). The black hatched line traces the landslide's main scarp. A continued, pronounced effect of the landslide dam on the longitudinal profile of the stream is evident

point bar attached to the opposite stream bank. A British Columbia, Ministry of Transportation and Infrastructure field investigation of the dam on August 22, 2013 determined that there was no imminent threat to the bridge or road infrastructure, and no mitigative action was taken.

\section{Saddle River landslide dam}

The June 1990 Saddle River landslide (Fig. 12) was a reactivated, retrogressive earth slide (Cruden et al. 1993). The landslide rupture surface, in advance phase glaciolacustrine sediment (LTA3), extended under the Saddle River, causing the streambed to be displaced southwards by $60 \mathrm{~m}$ and upwards by approximately $24.5 \mathrm{~m}$, creating a Type VI landslide dam (Cruden et al. 1993; Alberta 1997). The volume of water retained behind the dam was estimated at approximately $4 \mathrm{Mm}^{3}$ (McClung and Weimer 1990).

Overtopping of the dam began during the annual spring freshet of 1991 (Hanson 1994; Fig. 13), when a new channel formed at the toe of the landslide. Incision was slowed near the upstream edge of the dam, where the stream encountered the pre-landslide channel alluvium (Cruden et al. 1993). The alluvium was later bypassed when the channel widened (Hansen 1994). Continued incision into the dam was accompanied by progressive shortening of the lake (Table 2, Figs. 12, 13). By August 13, 2006, the lake had fully drained.

A longitudinal profile of the Saddle River, derived from the $2 \mathrm{~m}$ lidar data (dated October 22, 2013, Fig. 14), revealed approximately $14 \mathrm{~m}$ of sediment accumulation within the landslide lake basin. Therefore, incision into the dam amounted to $10.5 \mathrm{~m}$. A bathymetric survey of the basin, which ceased 7.25 years after the landslide in September 1997, recorded a final water depth of $14.8 \mathrm{~m}$ (Alberta 1997, Fig. 13). Beyond this time, very little further incision into the dam occurred despite the basin remaining flooded for up to another 9 years (August 2006; Table 2).

\section{Spirit River landslide dam}

The July 1995 Spirit River landslide was a reactivated and retrogressive earth slide that moved southwards by translation (Miller 2000). The emerging rupture surface at the toe

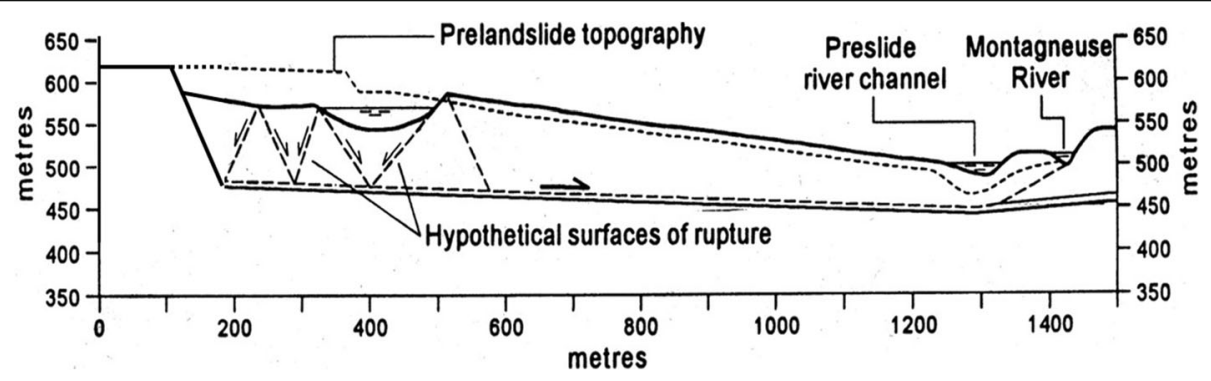

Fig. 9 Cross-section of the Montagneuse River landslide and dam. (Modified from Cruden et al. 1997) 


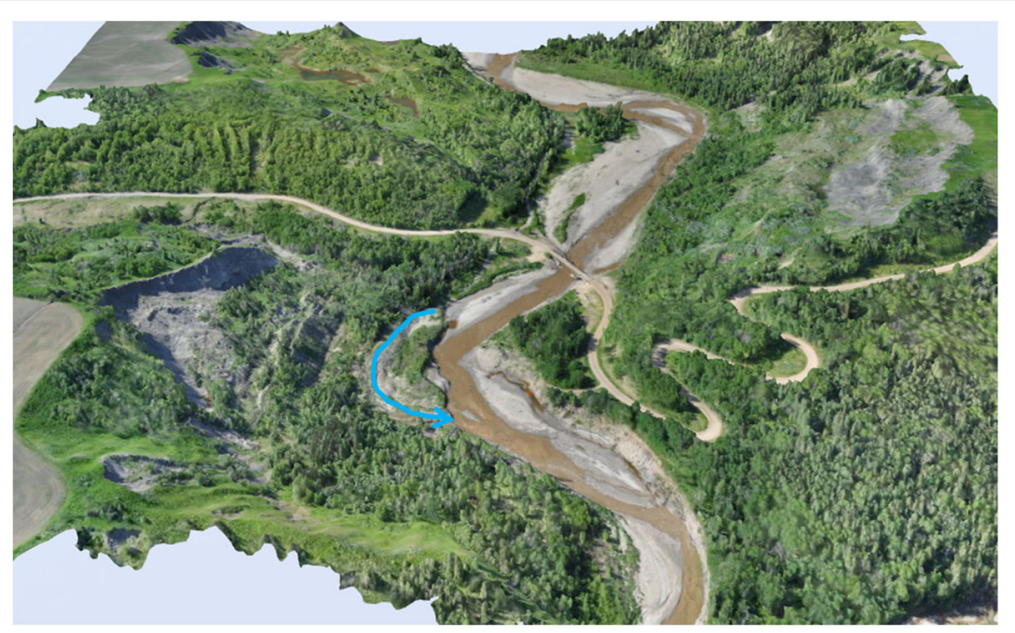

Fig. 10 Oblique aerial image mosaic of drone imagery, from June 2017, draped over a photogrammetrically generated digital elevation model depicting the Pouce Coupe River, and Landry Road and bridge (Source: Government of British Columbia; reproduced with permission). The 2013 landslide and dam are visible in the lower left. The approximate trace of the pre-landslide Pouce Coupe River channel is the blue line. The post-landslide stream channel cut through a point bar attached to the opposite stream bank, abandoning the pre-landslide channel

of the landslide was bounded above and below by glacial sediment (LTA4); however, as the rupture surface was trending upwards, it may have extended into underlying glaciolacustrine sediment (LTA3). An Alberta aerial photograph (Table 2), taken about 2 months after the landslide, shows a large lake upstream of the landslide and three smaller lakes along the length of the landslide. Our field survey in July 1999 found that the 3 smaller lakes had drained; thus, these lakes lasted for less than 48 months.
At its maximum, the large lake was approximately $2100 \mathrm{~m}$ long and $9 \mathrm{~m}$ deep (Miller 2000). The lake was impounded behind a pressure ridge that formed at the toe of the landslide. Our 1999 field survey found coarse alluvium was absent along much of the post-landslide channel, with the exception being just downstream of the large landslide lake, where the post-landslide channel encountered the coarse alluvium of the pre-landslide channel. This alluvium appears to be slowing drainage of

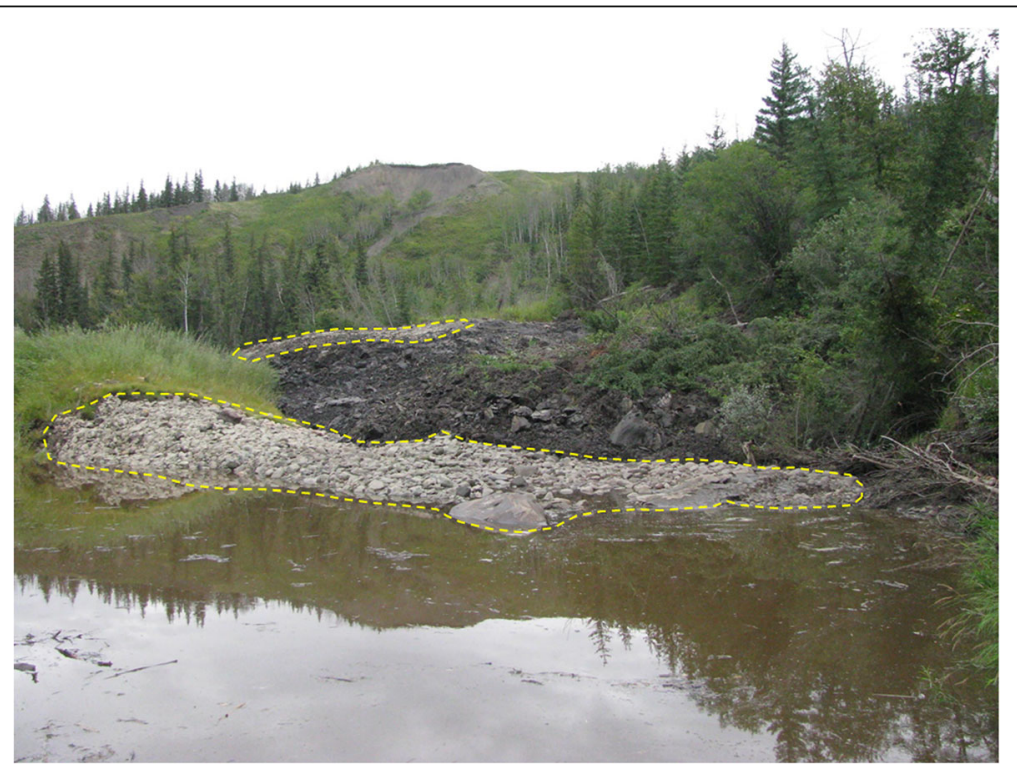

Fig. 11 The 2013 Pouce Coupe River landslide and dam, captured at the Landry Road bridge, looking downstream. The yellow polygons delineate uplifted channel alluvium. (Source: British Columbia Ministry of Transportation and Infrastructure, August 22, 2013; reproduced with permission) 

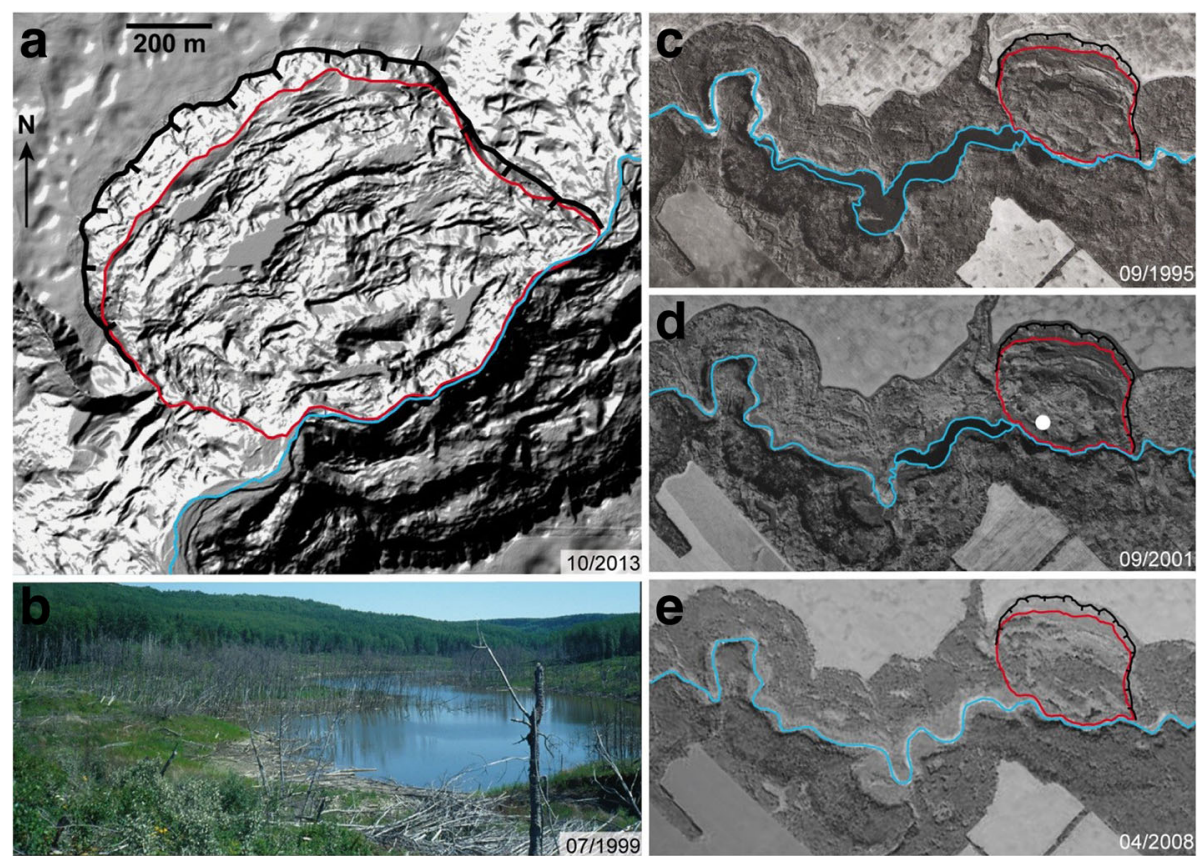

Fig. 12 The Saddle River landslide and dam. a. Digital Elevation Model derived using 2 m lidar data (dated October 22, 2013; source: Government of Alberta, reproduced with permission) showing the 1990 landslide colluvium (outlined in red) and mainscarp (black). b. The landslide lake in July 1999. Note the drowned timber within the landslide dam basin. (source: BGN Miller, July 1999.) c - e. Time series of aerial photographs showing the landslide dam lake in September 1995 and 2001, and the drained basin in August 2006 (air photos AS4680-33, AS5194B-40, and TRSG0602-1536 respectively; source: Alberta Environment and Parks, Air Photo Distribution, Copyright Government of Alberta, reproduced with permission). The white dot in $\mathbf{d}$ indicates the photograph location of $\mathbf{b}$

the lake. Digital Globe imagery, dated September 19, 2013, shows the lake continues to persist.

\section{Stability analysis}

Here, we test the ability of landslide dam stability indices from the literature to predict the observed behavior of our studied Type VI landslide dams. The stability indices we used are based on morphometric parameters (Canuti et al. 1998; Casagli and Ermini 1999; Ermini and Casagli 2003; Korup 2004; Tacconi Stefanelli et al. 2016). Table 3 lists the indices we assessed. Table 4 provides dam and watershed morphometric parameters for each of the landslide dams.
A landslide dam is considered unstable when it "has undergone erosion or collapse leading to a catastrophic breach, with the subsequent release of the impounded lake waters" (Ermini and Casagli 2003; p.32). Landslide dams are considered stable when they have not undergone a catastrophic breach and upstream lakes or infilled basins remain in place (e.g. Costa and Schuster 1988; Ermini and Casagli 2003; Korup 2004; Tacconi Stefanelli et al. 2016). We consider dams to be stable when the hazard of a catastrophic breach is low.

The calculated stability values for the described landslide dams are presented in Table 5. For these assessments, we use a dam volume equaling $10 \%$ of the

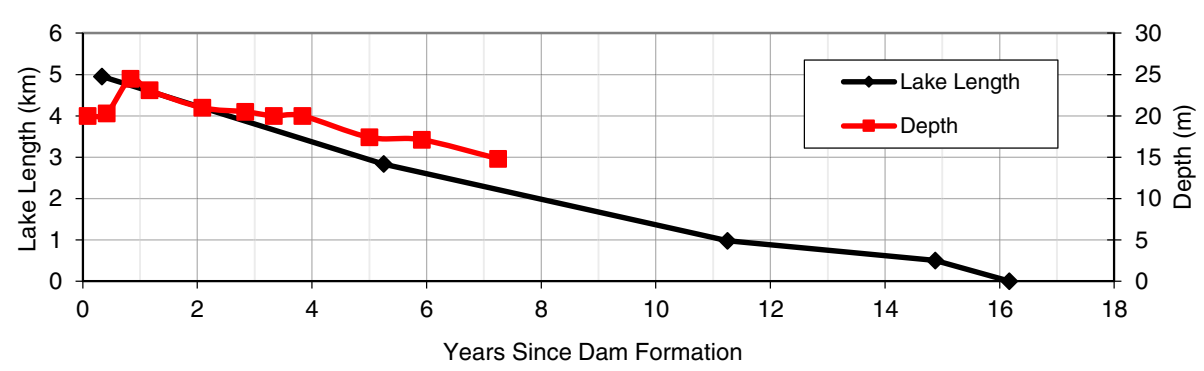

Fig. 13 Changes in the length and depth of Saddle River landslide lake since formation in June 1990. The depth data was derived from a bathymetry survey (Alberta 1997). The initial increase in the lake depth records basin flooding prior to the dam being overtopped 
Table 3 Landslide dam stability assessment indices assessed against the recorded behaviour of the Peace River regional landslide dams

\begin{tabular}{|c|c|c|c|c|c|}
\hline \multirow[t]{2}{*}{ Indices } & \multirow[t]{2}{*}{ Formula } & \multicolumn{3}{|c|}{ Published Thresholds } & \multirow[t]{2}{*}{ Reference and Region Applied } \\
\hline & & Unstable & Uncertain & Stable & \\
\hline Blockage & $B_{1}=\log \left(V_{D} / A_{C}\right)$ & $<4$ & $4-5$ & $>5$ & Canuti et al. 1998; Casagli and Ermini 1999 (Italy) \\
\hline \multirow[t]{2}{*}{ Impoundment } & $I_{1}=\log \left(V_{D} / V_{L}\right)$ & $<0$ & & $>0$ & Casagli and Ermini 1999 (Italy) \\
\hline & & $<1$ & & $>1$ & Korup 2004 (New Zealand) \\
\hline \multirow[t]{3}{*}{ Dimensionless Blockage } & $D B I=\log \left(A_{C} H_{D} N_{D}\right)$ & $>3.08$ & $2.75-3.08$ & $<2.75$ & Ermini and Casagli 2003 (world-wide) \\
\hline & & $>5$ & $3-5$ & $<3$ & Korup 2004 (New Zealand) \\
\hline & & $>3.98$ & $2.43-3.98$ & $<2.43$ & Tacconi Stefanelli et al. 2016 (Italy) \\
\hline Backstow & $I_{S}=\log \left(H_{D}^{3} N_{L}\right)$ & $<-3$ & $-3-0$ & $>0$ & Korup 2004 (New Zealand) \\
\hline Relief & $I_{R}=\log \left(H_{D} / H_{R}\right)$ & $<-1$ & & $>-1$ & Korup 2004 (New Zealand) \\
\hline \multirow[t]{2}{*}{ Hydromorphologic } & $\mathrm{HDSI}=\log \left(V_{D} / A_{C} S\right)$ & $<5.74$ & $5.74-7.44$ & $>7.44$ & Tacconi Stefanelli et al. 2016 (Italy) \\
\hline & & $<5.26$ & $5.26-8.07$ & $>8.07$ & Tacconi Stefanelli et al. 2017 (Peru) \\
\hline
\end{tabular}

landslide volume $\left(\mathrm{V}_{\mathrm{D}}\right.$ becomes $\mathrm{V}_{\mathrm{D} 10}$ in Table 3$)$. Based on cross-sectional profiles through the described landslides and dams, we found that only approximately $10 \%$ of the landslide volume goes into forming the dams. Figure 9 provides an example of the typical landslide and dam configuration in the Peace River region. Figure 9 shows that only a very small portion of the landslide is involved in the stream obstruction, with most of the landslide remaining out of the valley bottom.

The assessments produced 43 unstable, 19 uncertain, and 5 stable results. As these dams have not breached catastrophically, but rather continued to impound an existing or relict lake, they could not be considered unstable using the definition of Ermini and Casagli
(2003). Thus the indices are over-predicting unstable conditions.

\section{Discussion}

Each of the landslides we described had a basal rupture surface within the advance phase glaciolacustrine sediment (LTA3) or near the base of the glacial sediment (LTA4). The rupture surfaces extended under the channels causing the channels to be elevated, forming Type VI landslide dams. Type VI landslide dams appear to be common in the Peace River region, based on our field observations. In contrast, Type VI dams represent only $3 \%$ of the dams in Costa and Schuster's (1988) worldwide database of 184 dams.

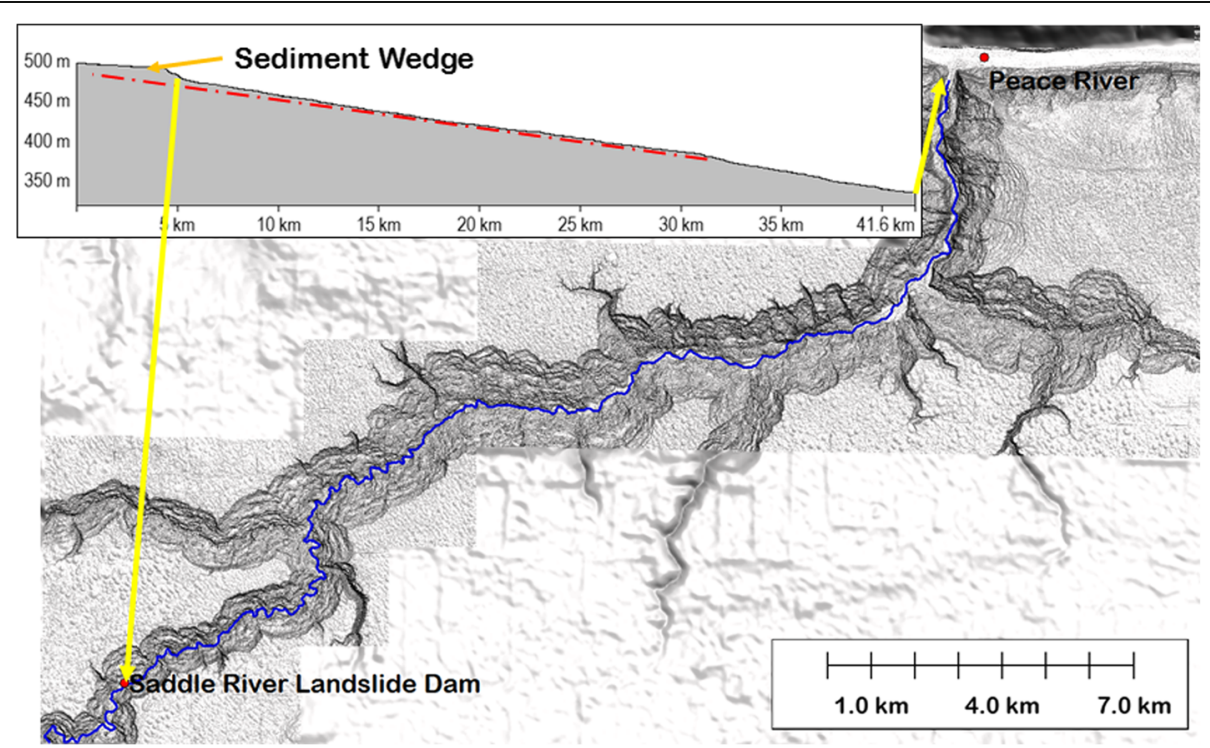

Fig. 14 Plan view and channel longitudinal profile of the Saddle River, generated from 2 m lidar data (dated October 22, 2013; source: Government of Alberta, reproduced with permission). The longitudinal profile extends from near the Peace River to approximately $4 \mathrm{~km}$ upstream of the landslide dam. The red line roughly follows the longitudinal profile of the lower Saddle River (below the landslide). The grey area situated above red line indicates areas of sedimentation upstream of the landslide dam 
Table 4 Morphometric parameters of the Peace River regional landslide dams

\begin{tabular}{|c|c|c|c|c|c|c|c|c|c|}
\hline \multirow[t]{2}{*}{ Attribute } & \multirow[t]{2}{*}{ Units } & \multirow[t]{2}{*}{ Symbol } & \multicolumn{7}{|c|}{ Landslide Dam } \\
\hline & & & Eureka & Fox & Hines & Montagn. & Pouce C. & Saddle & Spirit \\
\hline Landslide volume & $\mathrm{Mm}^{3}$ & $V_{D}$ & 50 & 47 & 48 & 78 & 2 & 39 & 20 \\
\hline Dam volume & $\mathrm{Mm}^{3}$ & $V_{D 10}$ & 5.0 & 4.7 & 4.8 & 7.8 & 0.2 & 3.9 & 2.0 \\
\hline Dam height & m & $H_{D}$ & 20 & 19 & 25 & 30 & 4 & 24 & 9 \\
\hline Lake volume & $\mathrm{Mm}^{3}$ & $V_{L}$ & 11 & 1.2 & 1.2 & & 0.34 & 4 & 0.26 \\
\hline Catchment area & $\mathrm{km}^{2}$ & $A_{C}$ & 1200 & 362 & 1055 & 95 & 2860 & 889 & 278 \\
\hline Relief upstream & $\mathrm{m}$ & $H_{R}$ & 510 & 213 & 296 & 373 & 478 & 429 & 254 \\
\hline Highest elevation in catchment & m & $E_{\max }$ & 1075 & 750 & 910 & 930 & 1015 & 1010 & 820 \\
\hline Elevation dam crest & $\mathrm{m}$ & $E_{\min }$ & 526 & 494 & 535 & 510 & 537 & 502 & 520 \\
\hline Longitudinal channel slope & $\circ$ & S & 0.2 & 0.2 & 0.2 & 0.2 & 0.1 & 0.2 & 0.2 \\
\hline
\end{tabular}

The landslide lakes diminish over several years through a combination of fluvial incision into the dams and deltaic and lacustrine sediment infilling of the basins. For the $24.5 \mathrm{~m}$ high Saddle River landslide dam, incision into the dam lowered the lake level by $10.5 \mathrm{~m}$, while $14 \mathrm{~m}$ of sediment infilling into the basin displaced the remaining water. At the Saddle River landslide dam, the draw-down of the lake level due to incision was initially more rapid (Fig. 13); however, after 7.25 years, when the last bathymetric survey was conducted, almost no further incision into the dam occurred, and most of the remaining lake water was displaced by predominantly deltaic sediment infilling of the basin. For the $20 \mathrm{~m}$ Eureka River landslide dam, incision brought the lake level down by $12 \mathrm{~m}$, while basin infilling amounted to $8 \mathrm{~m}$.

The rate of incision into the dams is known to be related to a number of factors including material type. The fine textured glaciolacustrine sediments (LTA3) tend to erode readily, but the incision may be slowed where the contemporary channel encounters the imbricated coarse alluvium of the pre-landslide channel. This phenomenon was observed at the Eureka, Saddle and

Table $\mathbf{5}$ Results of the assessment of landslide dam stability indices

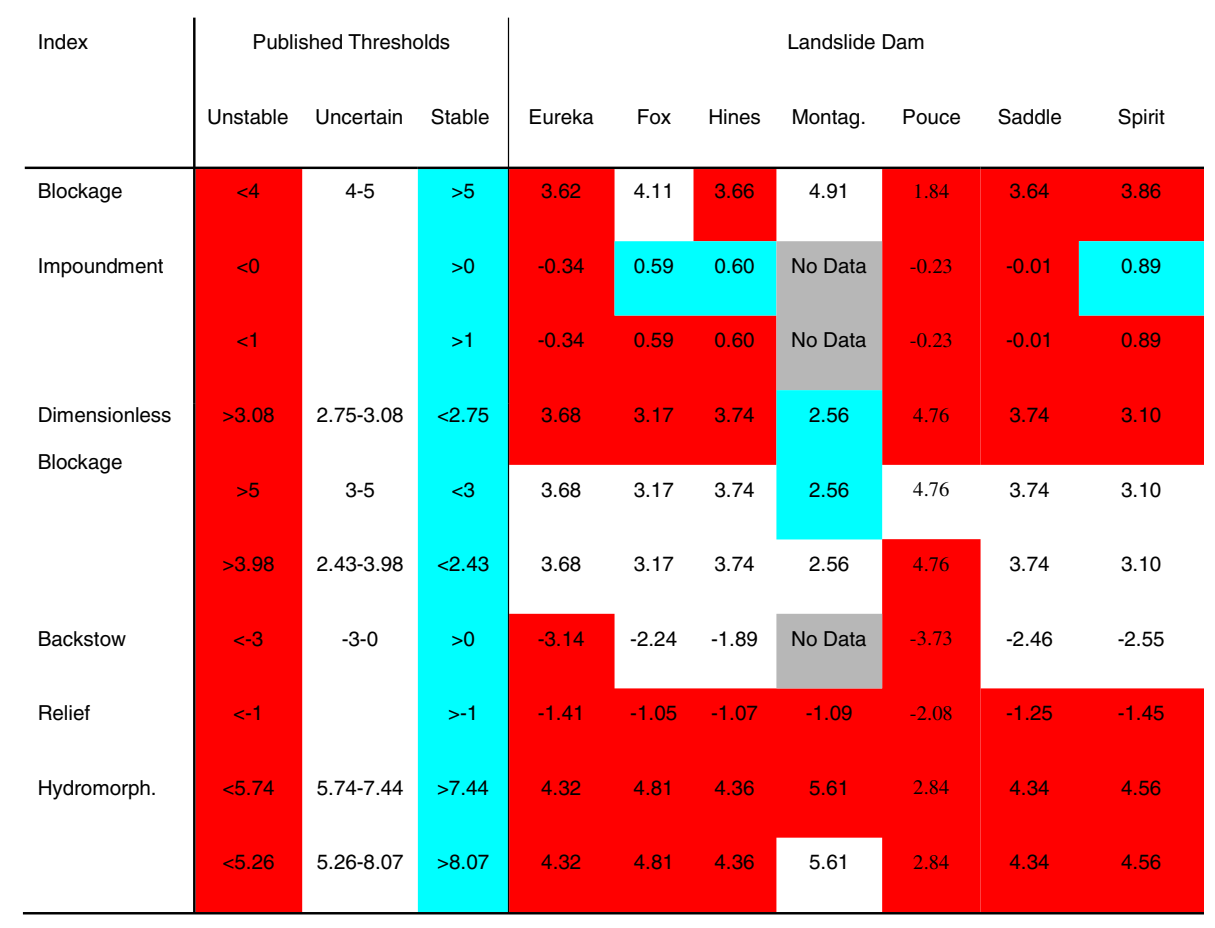

Red background indicates "unstable", blue indicates "stable", and white indicates "uncertain" stability 
Spirit River dams. The coarse alluvium was less effective at slowing incision once the clast imbrication had been upset (for example, the pre-landslide channel gravels that slid into the new Eureka channel were rapidly mobilized out of the reach as bedload (Miller and Cruden 2001, 2002)).

The long-lasting effects of the landslide dams on the tributary streams are evident in the persistent sediment accumulations upstream of the Montagneuse River and Hines Creek (pre 1952) landslide dam sites. These examples suggest that the sediment wedges observed behind the Eureka River, Fox Creek, and Saddle River dams (Figs. 6, 8, and 14) could take several decades to be fully mobilized, before the pre-landslide longitudinal profiles are re-established.

We found that the morphometric indices overpredicted dam instability (Table 5), using a realistic dam volume of $10 \%$ of the landslide volume. These indices also overestimated instability in the Halden Creek watershed, approximately $250 \mathrm{~km}$ northwest of our study area (Geertsema and Clague 2006). The databases that these empirical indices are derived from include a wide range of landslide types (from slow, smaller soil slides to large, rapid rock avalanches), and the determined thresholds might not be appropriate for the Peace River region's dams. Regional differences have already been noted by Korup (2004) and Tacconi Stefanelli et al. (2017). A larger dataset of Type VI landslide dams which are composed of glacial and glaciolacustrine sediments would facilitate the statistical evaluation of the significance of the various input parameters, and appropriate stability thresholds for these particular types of landslide dams might then be determined.

\section{Conclusions}

Our main findings for Peace River area landslide dams are as follows:

- The landslide rupture surfaces, in advance phase glaciolacustrine sediment or glacial sediment, extend under the channel causing the channel to be elevated and forming Type VI dam.

- The dams range in height from 4 to $30 \mathrm{~m}$.

- The post-landslide streams form new channels around the toes of the landslides.

- The landslide lakes can persist for up to 2 decades and diminish through a combination of dam incision and basin infilling.

- Incision into the dams is slowed when the postlandslide stream encounters the pre-landslide channel.

- More broad-based landslide dam stability indices, developed for other regions, poorly characterize the observed performance of the Type VI dams in our study.

\section{Acknowledgements}

We thank Tai Hoon Kim for providing data for the Fox Creek landslide and dam. Hans-Balder Havenith and a second anonymous reviewer provided insightful comments, which significantly improved the manuscript. The Government of Alberta provided access to and permission to reproduce the lidar images and air photos. Funding for this research was provided by the British Columbia Ministry of Forests, Lands, Natural Resource Operations and Rural Development, Alberta Geological Survey, and the Natural Sciences and Engineering Research Council of Canada.

\section{Availability of data and materials} N/A.

\section{Authors' contributions}

BM - Contributed to all sections. AD - Contributed to Stability Analysis and the Discussion sections. MG - Contributed to all sections except Stability Analysis, provided lidar and imagery. NA - Contributed to Regional Stratigraphy section, and provided lidar. HE - Analysed Pouce Coupe landslide and acquired data. DC - Contributed to Landslide Dams section. All authors read and approved the final manuscript.

\section{Funding}

British Columbia Ministry of Forests, Lands, Natural Resource Operations and Rural Development, Alberta Geological Survey, Natural Sciences and Engineering Research Council of Canada.

Ethics approval and consent to participate Not Applicable.

\section{Consent for publication}

Not Applicable.

\section{Competing interests}

The authors declare that they have no competing interests.

\section{Publisher's Note}

Springer Nature remains neutral with regard to jurisdictional claims in published maps and institutional affiliations.

\section{Author details}

${ }^{1}$ British Columbia Ministry of Forests, Lands, Natural Resource Operations and Rural Development, 499 George Street, Prince George, BC V2L 1R5, Canada. 2Engineering Geology and Hydrogeology, RWTH-Aachen University, Aachen, Germany. ${ }^{3}$ Alberta Geological Survey, Twin Atria Building Suite 402, 4999 - 98 Avenue, Edmonton, Alberta T6B 2X3, Canada. ${ }^{4} \mathrm{BC}$ Ministry of Transportation and Infrastructure, Suite 213, 1011 4th Ave, Prince George, BC V2L 3H9, Canada. ${ }^{5}$ University of Alberta, Civil and Environmental Engineering,

Edmonton T6H 1G9, Alberta, Canada.

Received: 28 August 2017 Accepted: 6 December 2017

Published online: 04 January 2018

\section{References}

Alberta. 1997. Saddle River landslide reservoir summary. Alberta Environment unpublished report. Grande Prairie.

Atkinson, N., and R.C. Paulen. 2010. Surficial geology and quaternary history of the Cleardale area, northwestern Alberta (NTS 84D/SW). Energy Resources Conservation Board, ERCB/AGS Open File Report: 2010, 27 p-2011.

Bayrock, L. 1969. Incomplete continental glacial record of Alberta, Canada. In Quaternary geology and climate, volume 16 of the proceedings of the VII congress of the International Association for Quaternary Research, H.E. Wright, $J r$, 99-103. Washington, D.C.: National Academy of Sciences.

Bobrowsky, P.T., and C.P. Smith. 1992. Quaternary studies in the Peace River district, 1990: Stratigraphy, mass movements and glaciation limits (94P), geological fieldwork 1991. British Columbia Geological Survey Branch, Ministry of Energy, Mines and Petroleum Resources, Paper 1992-1: 363-374.

British Columbia. 2014. Landry slide. British Columbia Ministry of Transportation and Infrastructure unpublished report. Dawson Creek.

Canuti, P., N. Casagli, and L. Ermini. 1998. Inventory of landslide dams in the northern Apennine as a model for induced flood hazard forecasting. In: 
Managing hydro-geological disasters in a Vulnerate environment, ed. K. Andah, 189-202. Perugia: CNR-GNDCl publication 1900. CNR-GNDCI-UNESCO (IHP).

Casagli, N., and L. Ermini. 1999. Geomorphic analysis of landslide dams in the northern Apennines. Transactions of the Japanese Geomorphological Union 20: 219-249.

Catto, N.R., D.G.E. Liverman, P.T. Bobrowsky, and N. Rutter. 1996. Laurentide, Cordilleran, and montane glaciation in the western Peace River - Grande Prairie region, Alberta and British Columbia, Canada. Quaternary International 32: $21-32$.

Costa, J.E., and R.L. Schuster. 1988. The formation and failure of natural dams. Geological Society of America Bulletin 100: 1054-1068.

Cruden, D.M., T.R. Keegan, and S. Thomson. 1993. The landslide dam on the Saddle River near Rycroft, Alberta. Canadian Geotechnical Journal 30: 1003-1015.

Cruden D.M., and D. Van Dine. 2013. Classification, description, causes and indirect effects - Canadian technical guidelines and best practices related to landslides. Geological Survey of Canada, Open File 7359, 22 pages.

Cruden, D.M., and D.J. Varnes. 1996. Landslide types and processes. In: Landslides: Investigation and Mitigation, Transportation Research Board, special report 247. Washington, D.C., USA: National Academy of Science.

Cruden, D.M., Z. Lu, and S. Thomson. 1997. The 1939 Montagneuse River landslide, Alberta. Canadian Geotechnical Journal 34: 799-810.

Ermini, L., and N. Casagli. 2003. Prediction of the behaviour of landslide dams using a geomorphological dimensionless index. Earth Surface Processes and Landforms 28 (1): 31-47.

Evans S.G., X.Q. Hu, and E.G. Enegren. 1996. The 1973 Attachie slide, Peace River valley, near Fort St. John, B.C., Canada: A landslide with a high-velocity flow slide component in Pleistocene sediment, $7^{\text {th }}$ International Symposium on Landslides, Balkema, Trondheim, Norway, 2: 715-720.

Fenton, M.M. 1984. Quaternary stratigraphy, Canadian prairies. In Quaternary stratigraphy of Canada, Geological Survey of Canada, Paper 84-10: 57-68.

Fletcher, L., O. Hungr, and S.G. Evans. 2002. Contrasting failure behaviour of two large landslides in clay and silt. Canadian Geotechnical Journal 39: 46-62.

Foord, V.N. 2016. Climate patterns, trends, and projections for the Omineca, Skeena, and Northeast, Natural Resource Regions, British Columbia. B.C. tech rep. 097. www.for.gov.bc.ca/hfd/pubs/Docs/Tr/Tr097.htm, 17 pp.

Geertsema, M., and J.J. Clague. 2006. 1000-year record of landslide dams at Halden Creek, northeastern British Columbia. Landslides 3: 217-227.

Geertsema M., and J.J. Clague. 2008. Natural dams, temporary lakes, and outburst floods in western Canada. Proceedings of the 1st World Landslide Forum, Tokyo Japan. 211-214

Geertsema, M., J.J. Clague, J.W. Schwab, and S.G. Evans. 2006. An overview of recent large landslides in northern British Columbia, Canada. Engineering Geology 83: 120-143.

Hanson, R. 1994. Saddle River landslide. Alberta Environment unpublished report. Grande Prairie.

Hartman, G.M.D., and J.J. Clague. 2008. Quaternary stratigraphy and glacial history of the Peace River valley, northeast British Columbia. Canadian J Earth Sciences 45: 549-564.

Holland, S.S. 1976. Landforms of British Columbia. A physiographic outline. British Columbia Department of Mines and PetroleumResources Bulletin 48.

Kim, T.H., D.M. Cruden, and C.D. Martin. 2010. The 2007 Fox Creek landslide, Peace River lowland, Alberta, Canada. Landslides 7 (1): 89-98.

Korup, O. 2004. Geomorphic characteristics of New Zealand landslide dams. Engineering Geology 73: 3-35.

Liverman, D.G.E., N.R. Catto, and N.W. Rutter. 1989. Laurentide glaciation in westcentral Alberta: A single (late Wisconsin) event. Canadian Journal of Earth Sciences 26: 266-274

Lu, Z.Y., D.M. Cruden, and S. Thomson. 1998. Landslides and preglacial channels

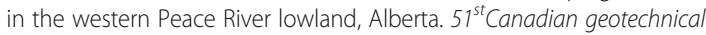
conference. Canadian Geotechnical Society, Edmonton, Alberta 1: 267-274.

McClung JE, and N. Weimer. 1990. Rycroft landslide geotechnical report. Geotechnical Branch, Development and Operations Division, Alberta Environment. Grande Prairie, file 8040-5-1.

Miller, B.G.N. 2000. Two landslides and their dams, Peace River Lowlands, Alberta. Master of Science Thesis, Department of Earth and Atmospheric Sciences, University of Alberta, Edmonton, Alberta.

Miller, B.G.N., and D.M. Cruden. 2001. Landslides, landslide dams and the geomorphology of tributaries in the Peace River lowlands, Alberta. $54^{\text {th }}$ Canadian geotechnical conference. Canadian Geotechnical Society. Calgary, Alberta. 1: 363-370
Miller, B.G.N., and D.M. Cruden. 2002. The Eureka River landslide and dam. Canadian Geotechnical Journal 39: 863-878.

Miller, B.G.N., and D.M. Cruden. 2008. Landslide dams, Peace River lowlands, Alberta. 61st Canadian geotechnical conference, Canadian Geotechnical Society. Edmonton, Alberta.

Miller, B.G.N., and D.M. Cruden. 2014. Landslide dams, Peace River lowlands, Alberta. Geological Society of America Conference, Vancouver, British Columbia.

Morgan A.J., R.C. Paulen, S.R. Slattery, and C.R. Froese. 2012. Geological setting for large landslides at the town of Peace River Alberta (NTS 84C). Energy Resources Conservation Board / Alberta Geological Survey, Open File Report 2012-04.

Tacconi Stefanelli, C., F. Catani, and N. Casagli. 2015. Geomorphological investigations on landslide dams. Geoenvironmental Disasters 2: 21.

Tacconi Stefanelli, C., S. Segoni, N. Casagli, and F. Catani. 2016. Geomorphic indexing of landslide dam evolution. Engineering Geology 208: 1-10.

Tacconi Stefanelli C, V. Vilímek, A. Emmer, and F. Catani. 2017. Morphological analysis and features of the landslide dams in the Cordillera Blanca, Peru. Landslides, https://doi.org/10.1007/s10346-017-0888-6.

\section{Submit your manuscript to a SpringerOpen ${ }^{\circ}$ journal and benefit from:}

- Convenient online submission

- Rigorous peer review

- Open access: articles freely available online

- High visibility within the field

- Retaining the copyright to your article

Submit your next manuscript at springeropen.com 